Søren Harck

A Phillips curve interpretation of error-correction models of the wage and price dynamics

Department of Economics 


\title{
A Phillips-curve interpretation of error-correction models of the wage and price dynamics
}

\author{
Søren Harck \\ Aarhus School of Business, \\ University of Aarhus \\ Department of Economics \\ Prismet, Silkeborgvej $2^{7}$ \\ 8000 Aarhus C, Denmark \\ (+45)89486410; fax (+45)86150188 \\ e-mail:soh@asb.dk
}




\section{Introduction}

\section{The model}

2.1 The wage- and price dynamics

2.2 The short-run Phillips curve

2.3 Wage share dynamics and the long-run wage share-curve $L W S$

2.4 The long-run Phillips curve $L P$

2.5 How are the short- and long-run Phillips curves related?

2.6 The demand side and the locus of stable employment LSE

2.7 The steady state

\section{Shocks: a brief, uninterpreted formal analysis}

\section{Shocks: a Phillips curve interpretation}

4.1 Loosening the nominal straightjacket: employment and wage share impact of a higher level of imported inflation

4.2 Employment and wage share impact of changing wage share targets

4.2.1 A change in workers' target share

4.2.2 A change in firms' profit share aspirations

4.3 Employment and wage share implications of changed wage- and price dynamics: a change in

4.3.1 the partial price-to-wage-inflation coefficient $(\alpha)$

4.3.2 the partial wage-to-price-inflation coefficient $(\delta)$

4.3.3 the error-correction coefficient of the wage dynamics $(\beta)$

4.3.4 the error-correction coefficient of the price dynamics $(\lambda)$

\section{Concluding remarks}




\section{Introduction}

Nowadays, the wage and price dynamics of applied macroeconometric models are typically described through some sort of error-correction mechanism, and references to the notion of the (non-vertical) Phillips curve have almost vanished. Indeed, is actually possible to come across the idea that modern error-correction formulations of the wage and price dynamics, pioneered by Sargan (1964), are outright incompatible with the old (and antiquated?) idea of a stable Phillips curve with finite slope ${ }^{1}$.

In this paper I wish to argue that, in an important sense, the notion of a stable Phillips curve should not be considered a futile relic of days long gone. More specifically, I wish to argue that the old Phillips curve can be a very convenient way of interpreting and summarizing many apparently much more modern-looking error-correction models of the wage and price formation ${ }^{2}$.

In section 2 I briefly present the model and develop the implied long-run relation between employment and, respectively, the wage share and the rate of inflation. Section 3 is actually in the nature of an appendix and is not crucial for understanding the reasoning of the paper: it only tries to document, scarcely with any words and without any attempt at interpretation, how various shocks affect the steady state of the model. Section 4 contains the basic argument of the paper: there I show quite explicitly how our rather typical, albeit stylized error-correction model, as well as shocks to this model, can be interpreted in terms of an old-fashioned Phillips curve (and, conversely, how this Phillips curve can be expressed in terms of the parameters of the underlying error-correction model). Section 5 offers some conclusions.

1 For instance, years ago Cripps stated that'"The Phillips curve hypothesis is false both because it assumes that market forces play a dominant role and because it is assumed that attempts to compensate for reductions or for inadequate increases in real earnings are of no importance." (Cripps (1977), p.111) The first reason adduced was refuted by Rowthorn (1977), who deserves the merit, among other things, of having shown that the expectation augmented vertical Phillips curve can (and should) be interpreted in terms of an immanent conflict between income share aspirations held by workers and capitalists (and that it does not, by itself, rest on the assumption "that money wages are determined by atomistic competition in the labour market" (Cripps (1977), p.110)). But neither does Cripps' second argument against the Phillips curve seem to stand up to closer scrutiny: one of the points of this paper is to bring out explicitly that the traditional Phillips curve is fully compatible with the idea that part of wage and price inflation reflects an attempt to compensate for previous disappointments concerning real earnings. More recently, and writing about the development of econometric models after 1970, Solheim has stated that "Equilibrium-correction terms, $[. .$.$] were taken into the models. As a result one could assure that the model's estimations were$ contained to a long-term trend. Thereby one could e.g. eliminate the possibility to pursue the Phillips curve indefinitely." (Solheim (2005), p.7; my italics)

2 Whitley (1994) seems to be expressing much the same view: "The overall impression is that some of the UK models have not really changed that much in their properties, despite their more acceptable theoretical underpinnings and their use of currently fashionable econometric techniques" (ibid., p.79) 


\section{2. $\quad$ The model}

\subsection{The wage- and price dynamics}

The basic model of the wage and price dynamics in this paper is exceedingly simple, and it looks as follows:

$$
\begin{aligned}
& d \log w=\alpha \cdot d \log P+\beta \cdot[\log F(N ; X)-\log \omega] \\
& d \log P=\delta \cdot d \log w+\lambda \cdot[\log \omega-\log \omega *]
\end{aligned}
$$

$w$ denotes the nominal wage, $P$ stands for the general price level (as measured by the GDP-deflator), and $\omega$ og $N$ designate the actual wage share ${ }^{3}$ and employment, respectively. Implicitly, the relative changes on the left hand side refer to relative changes per time unit and, strictly speaking, they therefore indicate rates of change. I shall assume that the parameters $\beta$ og $\lambda$ are both positive, whereas $\alpha$ and/or $\delta$ are less than one, but positive (this choice obviously amounts to assuming $\alpha \delta<1$ and will be justified below). For want of something better I have referred to $\alpha$ as the partial price-to-wage inflation coefficient (and analogously for $\delta$ ), whereas $\beta$ and $\lambda$ have been termed the error-correction coefficient (of, respectively, the wage and the price dynamics).

According to the wage relation (1), wage inflation depends positively on employment. More generally, it is assumed to depend on the unemployment rate, but since I shall assume, for simplicity only, that the growth rate of labour supply and labour productivity are both zero, unemployment easily translates into employment. Wage inflation is also assumed to be positively affected by price inflation, whereas it depends negatively on the actually prevailing wage share. The potential impact on the level of wage inflation exerted by institutional, "structural" variables is captured by the catch-all shift variable $X$. By convention, the elasticity of $F$ with respect to $X$ is equal to one. $F(N ; X)$ can naturally be interpreted as the wage share (or real wage) target held by wage earners: a higher gap between the target wage share $F$ and the actual wage share $\omega$ - i.e., a larger positive wage share error - is seen to trigger off higher wage inflation for any given price inflation. The interpretation of the price inflation equation is almost analogous: $\omega *$ can be interpreted as the wage share target (equal to one minus the profit share target) of capitalists or, in more contemporary usage, of firms ${ }^{4}$. Firms try to turn their markup or profit share targets into reality by adjusting prices appropriately. A higher gap between profit share aspirations and the actual profit share is seen to trigger off, by

\footnotetext{
3 In this paper I will assume, for simplicity, that labour productivity is constant. Therefore, we can talk interchangeably about the relative change of the wage share and the relative change of the real wage 4 Capitalists is the word used by, e.g., Rowthorn (1977), whereas Cassetti (2003), e.g., refers to firms instead
} 
itself, higher price inflation, thus contributing towards increasing the profit share and hence decreasing the wage share.

The model developed in this paper displays, to a varying extent, affinity with many previous post-Keynesian or Kaleckian models of growth (or output) and income distribution. In the following pages I will indicate this affinity by holding up the model against, in particular, Rowthorn's classic piece on conflict, inflation and money (Rowthorn (1977)) and the much more recent contribution by Cassetti (2003).

The wage and price dynamics posited by Cassetti is similar to (1) and (2), except for one thing ${ }^{5}$ : he did not include inflation (nor expected inflation) in his account of the wage dynamics, nor did he make room for wage inflation as a separate determinant of price inflation ${ }^{6}$. This amounts to assuming, in terms of (1) and (2), that $\alpha=\delta=0$. Cassetti's rationale for effectively ignoring the first terms on the right hand side of (1) and (2) is not entirely clear, but possibly the omission derives from the view that

The target wage share depends on several factors: inflation expectations, productivity changes, degree of militancy and bargaining strength. In our one-commodity model, where the income shares are defined in real terms, there is no need to include price expectations and productivity changes. In fact, workers react to the inflation rate or productivity increase to maintain their share, which otherwise would be eroded. Therefore, fixing a given share implies that inflation and productivity advances have been taken into account. ...[ibid., p.453]

In my view this is not convincing: it is not clear why the target wage share should depend on inflation expectations and productivity changes (and the meaning of income shares being defined in "real" terms does not seem obvious either). What seems clear enough, however, is that the wage inflation required in order to turn the target wage share into reality does in fact depend on inflation (expectations) and on the (expected) growth of labour productivity. Indeed, it's precisely by letting nominal wage growth react to the inflation rate and to productivity changes that workers can hope just to maintain their share. Therefore, and contrary to Cassetti's conclusion as embodied in his wage dynamics, if workers are really concerned about the wage share or even aiming at a certain target share, the logical implication seems to be that there is a need to include inflation (and productivity growth, which is here zero by assumption) on the right hand side in the wage dynamics. In (1), the target wage share is assumed to depend positively on the level of employment (and this of course is what accounts for the positive link between

\footnotetext{
An additional (but minor) difference is that wage and price inflation depends linearly on the absolute gap between the target and actual wage share, whereas wage and price inflation according to (1) and (2) is seen to depend linearly on the relative gap. My interpretation of $F(N ; X)$ corresponds to the interpretation given by Cassetti and is related to, but not totally coincident with the term the negotiated wage share used by Rowthorn

6 even though he (also) aknowledged that "workers will press for higher money wages until their share reaches the desired level" and that "firms try to close the gap between actual and target share by increasing prices" (ibid., p.453)
} 
between wage inflation and employment). This common assumption is also the assumption originally made by Rowthorn (ibid.), but it diverges from the the approach taken by Cassetti (ibid.), who assumes that workers' wage share target depends on the change of (un)employment rather than on the level of (un)employment ${ }^{7}$. As for the profit share target I have assumed, for simplicity, that it is exogeneously given.This, on the other hand, is fully in line with Cassetti but not with Rowthorn, who invoked the reasonable (but complicating) assumption that the profit share target increases with capacity utilization ${ }^{8}$ which, in turn, he proxied by (un)employment.

Not only do our equations (1) and (2) seem to capture the main thrust of many post-Keynesian formulations of the wage and price dynamics quite nicely. Despite the blatant simplicity of these error-correction equations, they also seem to capture the essence of the wage and price dynamics embedded in many large scale econometric models quite well. For example, the wage dynamics (1) is surprisingly close to the basic wage inflation equation of the SMEC-model of the Danish economy, developed and used by the Secretariate of the Economic Council in Denmark. Similarly, SMEC's basic price equation (describing the dynamics of the GDP-deflator) is almost identical to the price dynamics specified in (2) ${ }^{9}$.

It is a hallmark of all empirical macromodels of the Danish economy that at least one of the coefficients corresponding to the parameters $\alpha$ and $\delta$ is identified as being less than one: in SMEC, $\alpha$ is equal to 0.515 (DØRS (1999), p.15, p.93), and in the ADAM-model developed jointly by the The Statistical Bureau of Denmark and the Ministry of Finance, $\alpha$ is estimated as being equal to 0.462 (DS (1996), p.161). These parameter-estimates are generally reported as being highly significant and stable. Moreover, for the SMEC-model it is relatively easy to identify $\delta$ as being equal to 0.586 . (DØRS (1998), p.31)) ${ }^{10}$

It is exactly these apparent empirical facts which are lying behind the restriction $\alpha \delta<1$ that I imposed on these parameters right from the outset. And, as I will expound quite explicitly in the following, it is precisely when this assumption is met that it is possible to capture the core of the wage and price dynamics in even large macroeconomic error-correction models by means of an old-fashioned (long-run) Phillips curve with finite slope. This Phillips Curve may then be thought of as a convenient short-cut of a far more complicated model operating behind the

\footnotetext{
cf. Rowthorn (1977), p.219; Cassetti (2003), p.454

8 cf. Cassetti (2003), p.454; Rowthorn (1977), p.219. The basic reasoning of the present paper would not be affected if it were amended by (also) letting profit share aspirations be an increasing function of employment

9 this has been documented in detail in Harck (2005)

10 The wage relation of the MONA model developed by the Danish central bank does not include the wage share or the real wage as an argument of the wage equation, and this omission simplifies the wage -an price dynamics of the model. But also in model, "the estimated passthrough from [consumer price]inflation is less than one for one, and thereby the Phillips curve of MONA is not vertical, but downward sloping." (DN (2003), p.77 ff).
} 
stage. This property is not always fully acknowledged. For instance, even though it has gone totally undisputed that $\alpha$ is significantly less than one in the Danish SMEC-model, this model is, ironically, still claimed to imply what amounts to a vertical long-run Phillips curve: writing about the properties of SMEC, the fathers of the model (The Secretariate of the Economic Council) have stated that

In the short run the features are Keynesian in the sense that production is driven by demand [.....] However, also the supply side plays an important role in SMEC, and the long-run properties are a supply driven model with the labour force and technology as the binding constraints. (DØRS (1999), Introduction ${ }^{11}$ )

However, any model containing an error-correction specification of the wage and price dynamics with $\alpha \delta<1$ (and hence even the SMEC-model) is neither more nor less supply driven in the long run than what is being implied by the supply side embedded in a traditional Phillips curve with finite slope ${ }^{12}$. To substantiate this sweeping statement is what I will try to do in the following pages.

\subsection{The short-run Phillips curve}

Given $\alpha \delta<1$, (1) and (2) do indeed imply a well-defined Phillips curve with a finite slope: by combining (1) and (2) it is readily seen that price inflation can generally be written as

(3) SP: $\quad d \log P_{S R}=\frac{1}{1-a \delta} \cdot[\beta \delta \cdot(\log F(N ; X)-\log \omega)+\lambda \cdot(\log \omega-\log \omega *)]$

For given parameters, and for a given wage share, it seems entirely natural to think of this expression as the short-run Phillips curve: as usual, the rate of inflation depends positively on the level of employment. The only feature which may appear slightly unconventional is that the wage share is seen to play a role for the level of this short-run Phillips Curve. Whether a higher wage share will shift this Phillips curve upwards or downwards - or, to put it differently, whether a higher wage share is inflation-driving or inflation-dampening - appears to be ambiguous a priori. A higher wage share is seen to be inflation-dampening if $\beta \delta>\lambda$. This criterion is easy to interpret: in itself, a 1 percent increase in the wage share, e.g., will make price inflation increase by $\lambda$ percentage points, whereas it will make wage inflation decrease by $\beta$ percentage points and thereby make price inflation decline by $\beta \delta$ percentage points. If the second indirect effect dominates the first direct effect, the

\footnotetext{
11 Virtually the same quote can be found in the documentation of a new version of SMEC published after the submission of this paper to the Cambridge Journal of Economics in September 2006 (cf. DØRS (2007), Abstract)

12 clearly, if $\alpha=\delta=\alpha \delta=1$, the model is consistent for only one level of employment: the level $N^{*}$, at which targets of workers and firms are mutually consistent, implying that the aspiration gap (a term presumably coined by Rowthorn (ibid., p.217)), is equal to zero
} 
net result will be that a higher wage share is deflationary (i.e., decrease the level of price inflation at any given level of (un)employment).

\subsection{Wage share dynamics and the long-run wage share-curve $L W S$}

One can now ask what the wage and price dynamics in (1) og (2) implies for the dynamics and for the level of the wage-share. The answer is that, for any given level of employment, the wage share will gradually converge towards a certain stable level, and that this level turns out to be a weighted average of the wage share target of workers and firms, respectively. More specifically, it is possible to show that the wage share dynamics can be written as

$$
d \log \omega=\frac{\beta(1-\delta)+\lambda(1-\alpha)}{1-\alpha \delta} \cdot[L W S-\log \omega]
$$

where $L W S$ is the long-run wage share, towards which the actual wage share converges in a stable dynamic proces. $L W S$, in turn, can be written as

$$
\text { LSW: } \log \omega=\kappa \cdot \log \omega *+(1-\kappa) \cdot \log F(N ; X)
$$

where the weight $\kappa$ is a parameter defined exclusively in terms of the four characteristic parameters $\alpha, \beta, \delta$ og $\lambda$ of (1) and (2):

$$
\kappa \equiv \frac{\lambda \cdot(1-\alpha)}{\beta \cdot(1-\delta)+\lambda \cdot(1-\alpha)}
$$

In figure 1-1 I have depicted the $L S W$-locus. The vertical arrows indicate the the wage share dynamics leading towards it. Thus, in conjunction the wage and price dynamics are seen to imply that the long-run wage share will be positively related to the level of employment if $0 \leq \kappa<1$. However, it is also seen that neither the wage share aspirations of workers nor the profit share aspirations of firms will generally materialize: for $0<\kappa<1$, the long-run share will neither coincide with $\log F$ nor with $\log \omega *$ (save for the specific level of employment level where the two targets are consistent $)^{13}$.

It is only in some special cases that the long-run wage share will fully coincide with wage share aspirations: If $\delta=1$ and/or $\lambda$ is infinitely large, $\kappa=1$. This would imply that the wage share would converge, at any level of employment, towards the wage share target of firms. If, on the contrary, $\alpha=1$ and/or $\beta$ were infinitely large, it

13 Incidentally, if $\alpha$ and $\delta$ are put equal to zero, and if the profit share target of workers is specified, following Cassetti, as a negative and linear function of the growth rate (instead of employment), (5) readily degenerates into his so-called NAIPS-relation [ (17) and (18)] (non accelerating inflation profits share-relation) 
Figure 1: the basic employment and wage-share dynamics and the impact of a higher level of imported inflation

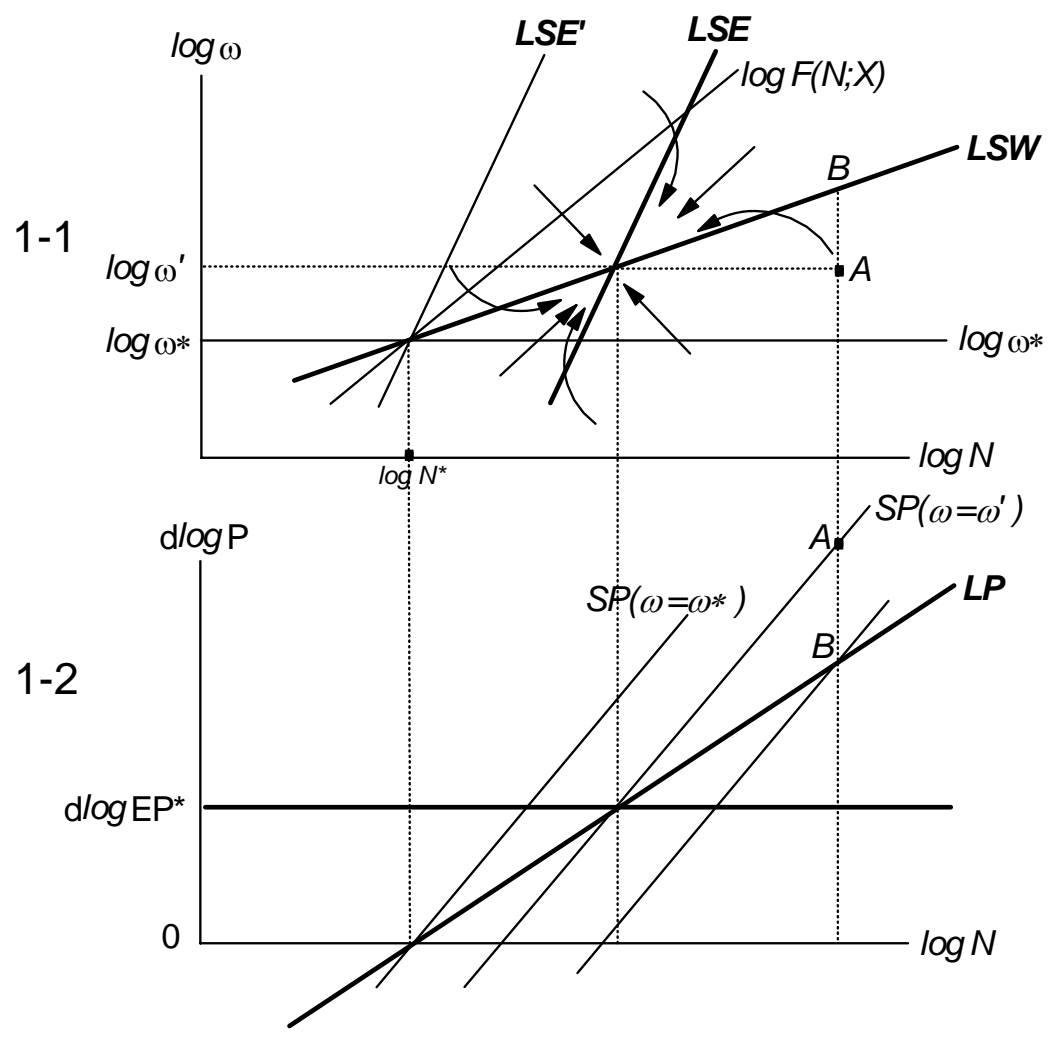

would be the wage share target of workers that would be turned into reality in the long run ${ }^{14}$ by the wage and price dynamics.

\subsection{The long-run Phillips curve}

The short-run Phillips curve (3) showed price inflation as a (positive) function of employment for a given wage share. However, since we have seen that, for any given level of employment, the wage share will converge asymptotically towards a certain stable level given by (5), it is now possible to specify the level of inflation corresponding to this stable wage share. By combining (3) and (5) we can derive inflation along the $L S W$-locus as

$$
\text { LP: } \begin{aligned}
d \log P & =\frac{1}{\left(\frac{1-a}{\beta}\right)+\left(\frac{1-\delta}{\lambda}\right)} \cdot[\log F(N ; X)-\log \omega *] \\
& =d \log P\left(\underset{+}{N} ; \underset{+}{X}, \omega_{-}^{*}, \underset{+}{\alpha} \underset{+}{\beta}, \delta_{+}, \lambda\right)
\end{aligned}
$$

14 Even though the interpretation of $\alpha(\delta)$ differs from the interpretation of $\beta(\lambda), \alpha$ and $\beta(\delta$ and $\lambda)$ are playing the same role, qualitatively speaking, in (5) as well as in several subsequent results 
The natural term for (6) is simply the long-run Phillips curve: evidently, if $\alpha \delta<1$ this long-run Phillips curve has a finite positive slope, and it simply shows, for any given level of employment, how large inflation will eventually be when the wage share has settled at the stable value given by (5). The merit of (6) is that it brings out explicitly how the long-run Phillips curve can be rationalized and expressed very simply in terms of the parameters and concepts of the underlying error-correction model (1) and (2) ${ }^{15,16}$.

\subsection{How are the short- and long-run Phillips curves related?}

The relation between the short- and long-run Phillips curves must obviously depend on whether a wage share increase is inflation-driving, inflation-dampening or inflation-neutral. It is easy to verify that the $L P$ - and $S P$-curves will coincide if a wage share increase is inflation-neutral (i.e., if $\beta \delta=\lambda$ ), and that the slope of the $S P$-curve will exceed the slope of the $L P$-curve if a wage share increase is inflation-dampening (i.e., if $\beta \delta>\lambda$ ) - and vice versa. Consequently, the $S P$-curve shown in figure 1-2 corresponds to the case where a wage-share increase will in itself make the inflation rate decrease. More generally, it is possible to derive that

$$
L P=S P-\frac{\beta \delta-\lambda}{1-a \delta} \cdot[L W S-\log \omega]
$$

where $L P$, $S P$ and $L S W$ are referring to (6), (3) and (5), respectively. If, at a given level of employment, there is initially a positive gap between the stable long-run wage share (towards which the economy converges) and the actual wage share, the actual short-run level of inflation (given by the $S P$-curve) will be higher than long-run inflation (given by the $L P$-curve) if a wage share increase is, all in all, inflation-dampening $(\beta \delta>\lambda)$.

15 Since, as previously suggested, Cassetti's recent model corresponds to the special case of (1) and (2) where $\alpha$ and $\delta$ are equal to zero, it is not surprising that (6) contains Cassetti's long run inflation equation [his equation (22)] as a special case. In this case, according to Cassetti, "inflation (or deflation) is generated by the aspiration gap [the term within the brackets in (6)] , and is exacerbated by indexation mechanisms, represented by the term $(1 / \beta+1 / \lambda)$." (ibid., p.455) Incidentally, the reference to $\beta$ and $\lambda$ and indexation parameters may not be quite appropriate. It is rather the parameters $\alpha$ and $\delta$ (which are implicitly equal to zero in Cassetti) which could potentially be interpreted as capturing an indexation mechanism

16 Rowthorn did not distinguish clearly between the actual wage share and the target wage share of workers, and his Phillips curve (which also contained anticipated inflation as an argument) was stated rather than explicitly derived. And unlike Cassetti's Phillips curve, it cannot be generated as a special case of (6) 


\subsection{The demand side}

Since it is my main endeavour to bring out, as simply as possible, how modern error-correction models of the wage and price dynamics can often be interpreted in terms of the (allegedly) old-fashioned Phillips curve, my account of the demand side will be rather crude and brief.

In many models - perhaps even in most models - conceived of as displaying typical post-Keynesian features, the economy is not nominally anchored: any rate of inflation is compatible with the steady state. Explicitly or implicitly it is commonly assumed that monetary policy in some form or another fully accomodates whatever level of inflation should materialize in the steady state. Inflation is certainly not dismissed as being an unimportant phenomenon, and often it is included among the variables being explored. However, because these models typically leave out any feedback from the level of inflation to (the growth of) real demand, inflation plays only a minor real role, if any at all. Effectively, the Phillips curve is turned into some sort of appendix which may be interesting in its own merits but nonetheless largely insignificant. This tradition is well represented by, among numerous examples, Cassetti (2003). However, it is not an approach universally adopted in the post-Keynesian tradition. For instance, in Cripps' account of inflation and unemployment, inflation was constrained, in the longer run, by a nominal anchor in the shape of an exogenously given growth rate of the nominal money supply: if unemployment were lower (and inflation were higher) than the values consistent with the constant steady state unemployment rate, output was posited to grow more slowly than "the productive potential", involving a rise in unemployment until the steady state was reached (cf. Cripps (1977), pp.103-104). Admittedly, Cripps may not himself have been especially devoted to the crucial assumption of an exogenous money supply. But at least Rowthorn was. In his seminal treatment of conflict, inflation and money he explicitly assumed that nominal money growth was exogenous; and not only did he just assume that real demand and output would grow whenever inflation was less than the given growth rate of nominal money: he even assumed that the growth rate of real demand and output was equal to the growth rate of real money (equal to an exogenous growth rate of the nominal stock of money minus inflation) (cf. Rowthorn (1977), p.230).

My description of the demand side resembles Cripps' approach and is not as restrictive as Rowthorn's: having a small open economy (like the Danish) in mind, I shall simply consider imported inflation, defined as the exchange-rate adjusted foreign rate of inflation, as a nominal anchor constraining (and containing) the level of domestic inflation in the long run. The crude demand-side assumption I invoke is that growth of real demand and real output will tend to exceed steady state growth (which, by assumption, is equal to zero) and hence increase employment whenever domestic inflation is less than the exogenously given level of imported inflation (and vice versa). When inflation has become equal to imported inflation, there will 
be no further systematic movement of employment (save for the short-run impact of unmodelled one-shot demand shocks):

$$
d \log N=H\left(d \log E P^{*}-d \log P\right) \quad H(0)=0 ; H^{\prime}>0
$$

Now, from (3) we know already that domestic inflation does not only depend on employment but also on the wage share. Obviously, this enables us to identify all couples of the wage share and the level of employment which would make domestic inflation coincide with imported inflation and which would therefore be consistent with stability of (un)employment: if the long-run steady-state property

$$
d \log E P^{*}=d \log P
$$

is grafted upon (3), we readily obtain this locus of stable employment, $\mathbf{L S E}$ :

(10) LSE: $\log \omega=\frac{1}{\beta \delta-\lambda} \cdot\left[-(1-a \delta) \cdot d \log E P^{*}+\beta \delta \cdot \log F(N ; X)-\lambda \cdot \log \omega *\right]$

If, on a net basis, a higher wage share is inflation-dampening ( $\beta \delta>\lambda)$, this locus is easily seen to have a positive slope. The reason for this is simple: lowering the wage share will increase inflation in this case, and a lower level of employment is therefore called for in order to keep inflation in line with the exogenously given imported inflation (which is a necessary condition for keeping employment stable) ${ }^{17}$ . In this paper I have simply assumed that a higher wage share is inflation-dampening, implying a positive slope of the $L S E$-locus ${ }^{18}$. To the left of the relevant $L S E$-locus (whether negatively or positively sloped), domestic inflation will be less than imported inflation, and employment will therefore be increasing (and vice versa).

\subsection{The steady state}

According to this model, higher employment means a higher long-run wage share (save for the special case with $\delta=1$ and/or $\lambda$ infinitely large). This is what the $L S W$-locus says. At the same time, however, a higher wage share means higher

17 Holden\&Nymoen take it for granted, apparently, that my assumption holds in general when they write that "A high level of unemployment does have a dampening effect on wage growth. But if lower wage growth reduces the wage share, this counteracts the dampening effect [on wage and price inflation] of high[er] unemployment" (Holden\&Nymoen (2002), p.101). However, whether or not a higher wage share is inflation-dampening seems, rather, to be an empirical question. In the Danish SMEC-model referred to earlier, $\beta, \delta$ and $\lambda$ are roughly equal to $0.25,0.60$ and 0.70 , respectively. In this specific model a higher wage share is therefore inflation-driving, corresponding to a negatively sloped LSE-locus

18 It can be shown that the positive slope of this case will unambiguously exceed the slope of the $L S W$ locus 
long-run employment in this case (where, by assumption, a higher wage share is assumed to be deflationary). This is what the LSE-locus tells us. The steady state corresponds, of course, to the intersection between these two loci (cf. figure 1-1). The arrows seem to suggest that the wage share and employment dynamics is uncomplicated, and that the model is locally stable ${ }^{19}$. If the economy should momentarily be located in a point such as point A (perhaps as a consequence of a permanent one-shot shock to the level of real demand), the wage-and price dynamics seem to indicate a path towards the steady state, along which employment will be decreasing, whereas the wage share will first tend to increase but eventually get back to its initial value. The mechanism behind the employment dynamics appears particularly transparent in figure 1-2: if unemployment stayed unchanged, the wage share would gradually converge towards the stable level corresponding to point B on the $L S W$-locus, and the short-run Phillips curve $S P$ would drift downwards until the wage share had stabilized and inflation had declined to the level indicated by point B on the long-run Phillips curve $L P$ in figure 1-2. But employment does not stay constant: it obviously decreases as long as the level of inflation still exceeds the level of imported inflation indicated by the horizontal line in figure 1-2. I have not dealt explicitly with the implied inflation dynamics (as opposed to the dynamics of the price level), and I am therefore prevented from indicating, in figure 1-2, the full employment-inflation path corresponding to the employment-wage share path sketched in figure 1-1. But if the latter path is stable, the employment-inflation path, however it may look in detail, must clearly enough approach the intersection point between the long-run Phillips curve and the horizontal "imported inflation-line" in a gradual and smooth way.

\section{Shocks: a brief, uninterpreted formal analysis}

We are now ready to explore how a change in one or more parameters of this simple model affects the steady state (and also to sketch how this steady state is approached). The real problem is not to show formally how employment and the wage share are affected by such changes. This is slightly tedious but is easily done, in principle, by totally differentiating the model consisting of (1), (2) and the necessary steady state condition (9) ${ }^{2021}$. This gives us

\footnotetext{
19 This impression can indeed be confirmed by formal analysis (cf. Harck (2002))

20 Alternatively, one could totally differentiate the LSE- and LSW loci. It turns out, however, than even though the results are obviously totally invariant to the choice of procedure, the expressions appear less complicated through the procedure chosen here

21 There is no need, of course, to include the change of the inflation rate among the endogenous variables in this calculation, since it is immediately determined by (9)
} 


$$
\left|\begin{array}{cc}
\beta & -\beta \cdot \varepsilon \\
-\lambda & 0
\end{array}\right| \times\left|\begin{array}{c}
\Delta \log \omega \\
\Delta \log N
\end{array}\right|=\left|\begin{array}{c}
-(1-\alpha) \cdot \Delta\left(d \log E P^{*}\right) \\
+\beta \cdot \Delta \log X \\
+d \log E P^{*} \cdot \Delta \alpha \\
+(1-\alpha) E P^{*} \cdot(\Delta \beta / \beta) \\
-(1-\delta) \cdot \Delta\left(d \log E P^{*}\right) \\
-\lambda \cdot \Delta \log \omega^{*} \\
+d \log E P^{*} \cdot \Delta \delta \\
+(1-\delta) \cdot d \log E P^{*} \cdot(\Delta \lambda / \lambda)
\end{array}\right|
$$

where $\varepsilon$ signifies the elasticity of the workers' wage share target $F$ with respect to employment $N$ :

$$
\varepsilon \equiv \partial \log F(N ; X) / \partial \log N
$$

In principle, it is easy to calculate from the two equations given in (11) how the steady-state employment and the wage share will be affected by changes in one or more of the parameters: the full solution of (11) with respect to the change of employment and the wage share can compactly be written as

$$
\begin{aligned}
& \Delta \log \omega= \\
& \left|\begin{array}{cccccc|c|}
\frac{1-\delta}{\lambda} & 0 & 1 & 0 & 0 & -\frac{1}{\lambda} \cdot d \log E P^{*} & -\frac{1-\delta}{\lambda} \cdot d \log E P^{*} \\
\frac{1}{\varepsilon} \cdot\left[\frac{1-\delta}{\lambda}+\frac{1-a}{\beta}\right] & -\frac{1}{\varepsilon} & \frac{1}{\varepsilon} & -\frac{1}{\varepsilon \cdot \beta} \cdot d \log E P^{*} & -\frac{1-a}{\varepsilon \cdot \beta} \cdot d \log E P^{*} & -\frac{1}{\varepsilon \cdot \lambda} \cdot d \log E P^{*} & -\frac{1-\delta}{\varepsilon \cdot \lambda} \cdot d \log E P^{*}
\end{array}\right| \times\left|\begin{array}{c}
\Delta\left(d \log E P^{*}\right. \\
\Delta \log X \\
\Delta \log \omega * \\
\Delta a \\
\Delta \beta / \beta \\
\Delta \delta \\
\Delta \lambda / \lambda
\end{array}\right|
\end{aligned}
$$

Whereas it may be easy enough to carry out this formal exercise, the real and remaining problem is, however, how to make sense of these results. But fortunately comprehension is greatly facilitated if these changes are envisaged and interpreted in terms of the $L S W$ and $L S E$ loci, and not least in terms of the long-run Phillips curve $L P$. This is the task to which I now turn. 


\section{Shock-effects: a Phillips curve interpretation}

\subsection{Loosening the nominal straightjacket: the impact of a higher level of imported inflation}

Let us first look at the consequences of relaxing the nominal anchor. More specifically, the question is what would happen if there were a certain increase in imported inflation. Inspection of (5) and (10) immediately reveals that the $L S W$-locus will be entirely unaffected, whereas the $L S E$-locus will shift to the right (quite irrespective of its slope). This is shown in figure 1-1, where the locus $L S E^{\prime}$ corresponds to the inital level of imported inflation (assumed here to be equal to zero). Obviously, long-run employment will increase, and in all cases where the $L S W$-locus is positively sloped (i.e., if $\delta<1$ and/or $\lambda$ is less than finite), the wage share will therefore increase as well.

According to the first column on the right hand side in (13), the employment effect of a changed level of imported inflation is given by

$$
\Delta \log N=\left[\left(\frac{1-\delta}{\lambda}+\frac{1-\alpha}{\beta}\right) \cdot \varepsilon^{-1}\right] \cdot \Delta\left(d \log E P^{*}\right)
$$

It is particularly easy to make sense of this result if reference is made to the shortand long-run Phillips curves depicted in figure 1-2, and if it is noted (by glancing at (6) and (12)) that the term within the bracket is nothing but the inverse of the slope of the long-run Phillips curve. Higher imported inflation (from 0 to the level indicated by the bold horizontal line in figure 1-2) simply sparks off an interim period with expansion of employment which lasts as long as domestic inflation is still lower than the now higher imported inflation. By itself, the expansion of employment will tend to increase domestic inflation (along a relatively steep short-run Phillips curve $S P$ ), whereas the induced growth of the wage share will, by assumption, tend to dampen inflation (meaning a downward shift of the short-run Phillips curve). However, the long-run net effect is that domestic inflation increases as employment expands. This net effect is captured by the long-run Phillips curve $L P$.

Evidently, the lower the slope of the $L P$ curve, the larger will be the positive long-run impact on steady state employment. How this slope, in turn, depends on the parameters of the underlying error-correction model of the wage and price setting appears quite explicit in (6) (and (14)). It is not surprising, therefore, to see that lower values of $\alpha, \beta, \delta, \lambda$ and $\varepsilon$ (the elasticity of workers' wage share target $F$ with respect to employment $N$ ) will make the ensuing expansion larger. Explained in terms of the long-run Phillips curve the reason simply is that lower values of these parameters will all make the long-run Phillips curve flatter.

Qualitatively, it is easy to figure out what happens to the wage share: the LSW locus is totally unaffected by this shock, and since employment increases, the wage share 
must increase except for the case special case where $\delta=1$ and/or $\lambda$ is infinitely large: this special case would imply a horizontal $L S W$ locus, and the wage share share would therefore be totally unaffected. All this is confirmed by (12), according to which the wage share effect can be written as

$$
\Delta \log \omega=\frac{1-\delta}{\lambda} \cdot \Delta\left(d \log E P^{*}\right)
$$

It is worth noting that no parameters at all of the wage dynamics in (1) appear in this expression. Hence, the wage share impact of higher imported inflation is totally independent of nominal wage behaviour (as captured by (1)). This feature applies more generally within this model: in fact, the steady state value of the wage share can easily be derived, recursively, from (2) and (9) alone, without making any use of (1). Hence, the wage share impact of any shock will be totally independent of (the parameters describing) nominal wage behaviour. However, even though this is a general feature within this model, it is a special feature of this model: it simply originates from having assumed that the wage share target of firms (as opposed to workers) is exogenous and therefore independent of employment. With a more symmetrical assumption (in line with, e.g., Rowthorn), even the wage share would depend on the wage behaviour outlined in (1).

As hinted at earlier, the Danish SMEC-model does not exhibit dynamic homogeneity in the sense that $\alpha$ and $\delta$ are not both equal to one (and the same applies to all the other macroeconometric models of the Danish economy). In the SMEC model these parameters are estimated as 0.515 and 0.586 , respectively, and $\beta, \lambda$ and $\varepsilon$ can be identified as, respectively, 0.244 and 0.695 and 3.11 (cf. Harck (2005)). If these findings are taken at face value, a back-of-the-envelope calculation readily shows that a 1 percentage point increase in imported inflation would, in the long run, make employment increase by almost 1 per cent ${ }^{22}$, and lead to an increase in the wage share by rather more than a $1 / 2$ per cent.

\subsection{Employment and wage share impact of changing wage share targets}

\subsubsection{An increase in workers' wage-share target}

Let us now ask what happens if, for some unexplained reason, wage share aspirations held by workers goes up. In the present framework such a structural change can obviously be captured by a shift in the catch-all variable $\mathrm{X}$ in $(1)^{23}$.

${ }^{22}$ Corresponding to this, these numbers imply that the slope (the change of inflation per 1 percent change of employment) of the long-run Phillips curve would equal 1.21

${ }^{23}$ Actually, a shift of X could also capture, qualitatively, (the impact of) a change of the elasticity $\varepsilon$ of workers' wage target with respect to employment: save for second order change, a higher value of $\varepsilon$ (which implies a higher slope of $F(N ; X)$ and hence of $L P$, can be modelled as an upward shift of the the $F(N ; X)$ - and $L P$-curve 
According to (13), employment will be unambigously negatively affected: the change of employment will be given by

$$
\Delta \log N=-\frac{1}{\varepsilon} \cdot \Delta \log X
$$

The lower the employment elasticity of workers' wage share target, the higher will be the long-run drop of employment following from, e.g., a 1 percent increase in the wage target level.

Once more, the Phillips curve turns out to be a most convenient shortcut when trying to interpret this result: an increase in workers' wage share target means that the long-run Phillips curve shifts upward with by an amount depending on the four parameters $\alpha, \beta, \delta$ and $\lambda$ (cf. (6)). However, the leftward shift, which corresponds to the employment effect, depends only on $\varepsilon$ (cf. (6)) and is simply given by (16). If employment remained constant, the wage and price dynamics would definitely bring about, eventually, an increase in the actual wage share, even though this increase would be less than the increase in the target: in relative terms, the upward

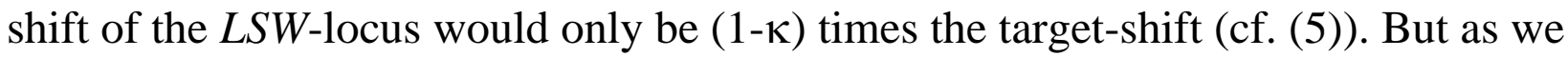
have just established, employment will not stay constant: at any given level of employment, inflation will eventually increase (cf. (6)), and as long as domestic inflation still exceeds the given level of imported inflation, employment will tend to drift downwards. In this model, where domestic inflation vis-à-vis imported inflation plays a crucial role for the development of employment, long-run employment is therefore bound to decline. In terms of figure 2-1, the LSE-locus (reflecting domestic inflation being equal to imported inflation) shifts to the left, and this leftward shift will equal the leftward shift of the $L S W$-curve (which, in turn, will be equal to the leftward shift of the $L P$-curve). The wage share declining effect of lower employment is seen to offset, precisely, the increase in the wage share that would have taken place had employment been unaffected. This is fully consistent with our earlier suggestion, according to which nominal wage behaviour is devoid of any impact at all upon the actual wage share in this model (and it is also, of course, consistent with (13))

However simple this model may appear, it still captures, in my view, the gist of the wage and price dynamics of many large-scale econometric models. In particular, it comes very close to the structure of wage and price formation in the Danish SMEC model. And according to this specific model a higher wage share target on part of workers does indeed imply lower long-run employment, but an unchanged actual wage share. On the other hand our conclusions do not square completely with the conclusions arrived at in some of the post-Keynesian models referred to earlier: in Rowthorn's celebrated model, higher "working class militancy" also implies a decline of steady-state employment, but at least it brings about a shift of distribution in favour of wages. According to Cassetti (2003), however, the attempt to push for a higher wage share (or real wage) will be successful in more than one respect: not 
Figure 2: increasing wage share targets of workers

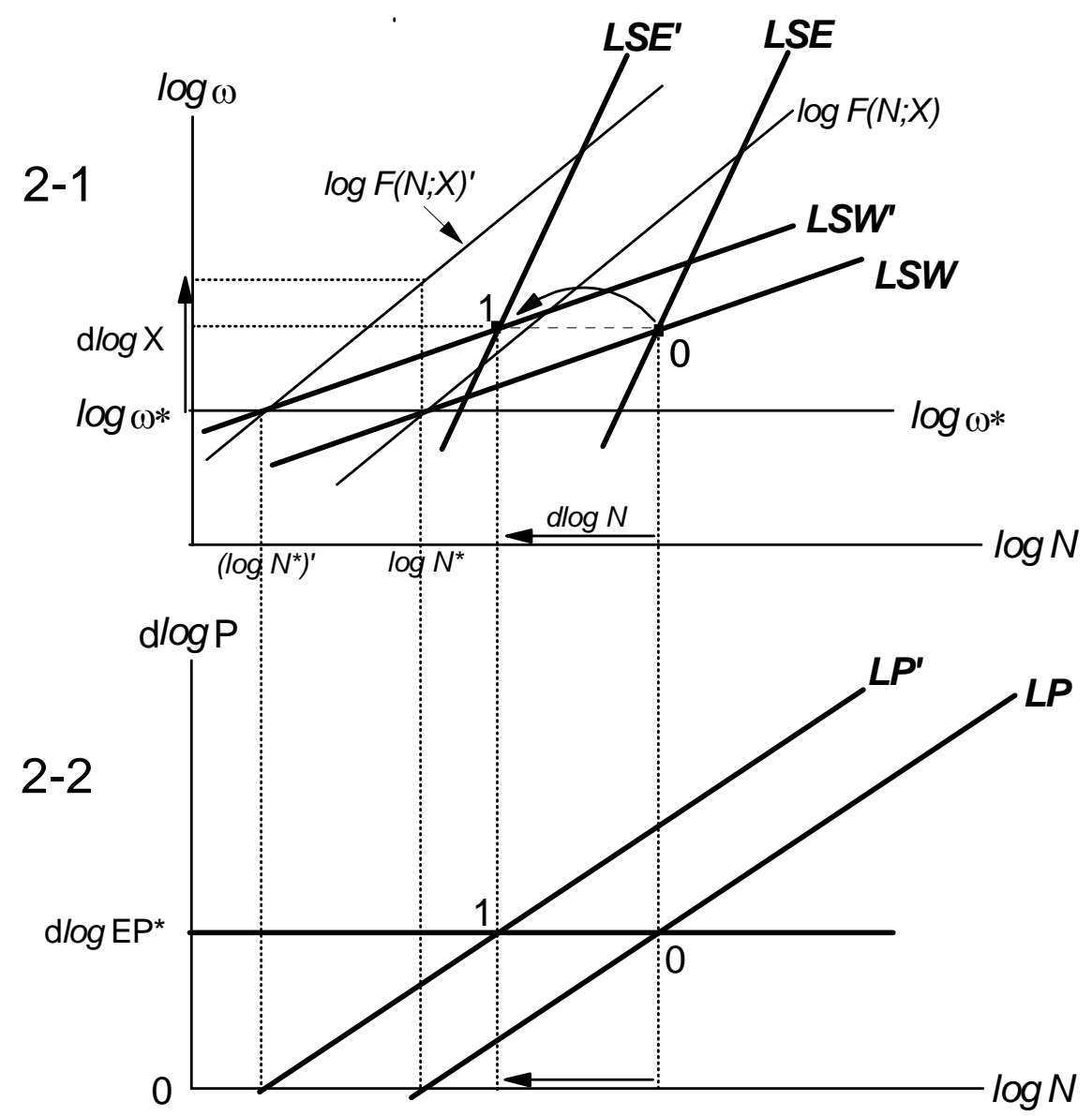

only will the actual wage share increase, but employment will go up as well ${ }^{24}$. How can these differences vis-à-vis our model be explained? The very marked difference between Cassetti's and our conclusion can basically be attributed to the fact that, in his model, (growth of) real demand is completely immune to the level of domestic inflation. The difference vis-à-vis Rowthorn's results is actually rather modest: Rowthorn assumed that the wage share target of firms $(\omega *)$ was negatively related to capacity utilization, which he proxied by (un)employment. It is not difficult to see that if we had adopted this assumption as well our LSW-locus could possibly have been negatively sloped. And if this were the case we would also have to conclude that higher "militancy" on part of workers would indeed be productive in

${ }^{24}$ See Cassetti (2003), pp.457-458. The fact that the wage share target depends on employment growth rather than on the level of employment in Cassetti is one reason why a strict comparison with our model is not entirely straightforward. With this proviso, however, even Cassetti's demand side can be conceived of in terms of a positively sloped LSE-locus. But the nature of the LSE-locus inherent in his analysis is very different from our: 1) the position of his LSE-locus is totally independent of the level of inflation 2) the positive slope of his LSE-locus reflects the familiar assumption that a redistribution in favour of wages implies, in itself, a higher level of effective demand. In terms of our geometry, Cassetti's result could be interpreted as corresponding to the intersection between an unchanged LSE-locus and a (somewhat simpler) $L S W$-locus which has shifted upwards 
terms of the actually realized wage share (but still counterproductive in terms of employment).

\subsubsection{A change of firms' profit share aspirations: a decrease (increase) in the profit share (wage share) target of firms}

The implications of lower profit share aspirations on part of firms ${ }^{25}$ are shown in figure 3. As in the previous case, for any given level of employment, this change will indeed make the profit share decrease in the long run: the $L S W$-locus shifts upward, but as seen from (5) the shift will not generally be equal to the upward shift following from a change in workers' wage share aspirations. From (10) it is easily inferred that the LSE-locus will now shift to the right. This just reflects that a lower profit target (or, equivalently, a higher wage target on part of firms) is unambiguously anti-inflationary (which can be seen from (3)). At any level of the actual wage share employment therefore now has to be larger in order to generate a domestic inflation rate equal to the given level of imported inflation. As visible in figure 3 , the effect on employment is therefore unequivocally positive. From (13) we get this positive employment effect as

$$
\text { (17) } \Delta \log N=\frac{1}{\varepsilon} \cdot \Delta \log \omega^{*}
$$

Hence, the employment effect of higher wage share (lower profit share) aspirations on part of firms is numerically identical but opposite in sign to the employment effect of higher wage share aspirations on part of workers. If this is conceived of in terms of the long-run Phillips curve it is again easy to interpret this result: an increase in $X$ by, say, $1 \%$ makes the long-run Phillips curve shift upwards by $1 \%$ times the coefficient in front of the bracketed "error"-term in (6). If, on the other hand, $\omega *$ is increased by $1 \%$, the long-run Phillips curve will shift downwards by the same amount. Hence, the size of the leftward shift in the first case will equal the size of the rightward shift in the second case. And since long-run inflation is given parametrically by imported inflation, the leftward and rightward shifts of the long-run Phillips curve indeed correspond to the long-run employment effects, and they are given by (16) and (17), respectively.

According to (13) the long-run impact on the wage share can be written as

$$
\Delta \log \omega=1 \cdot \Delta \log \omega^{*}
$$

25 instead of talking about lower profit or higher wage share aspirations on part of firms, the matter could obviously have been phrased in terms of the target markup 
Figure 3: a decline of profit aspirations

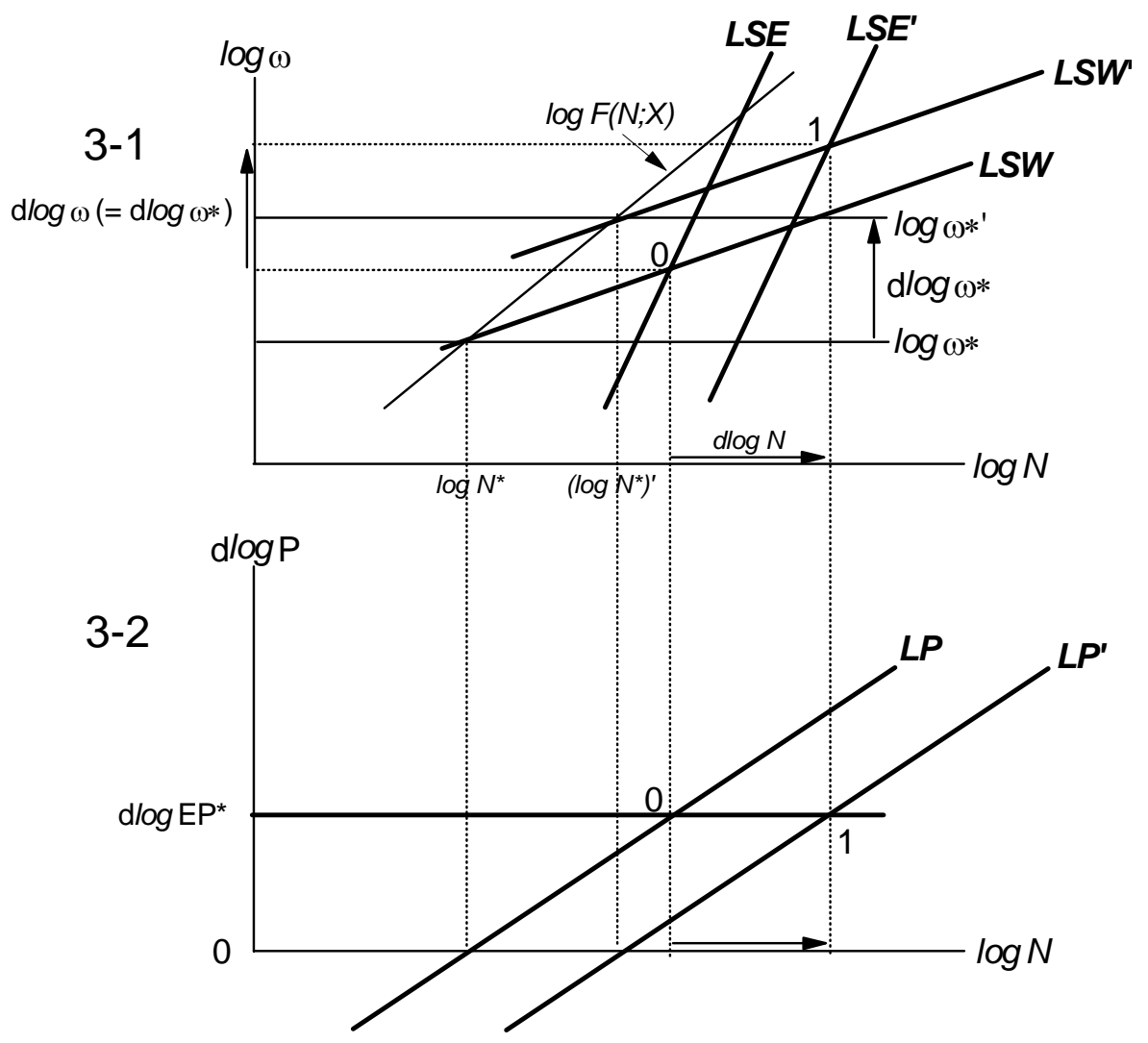

In the long run, therefore, higher wage share aspirations on part of firms are transmitted into a higher actual wage share, and in relative terms the transmission is one for one ${ }^{26}$.

Conversely, higher profit share aspirations will indeed entail a higher actual profit share, but lower long-run employment (and activity). The implications for total profits (and hence for profitability) therefore appears an open question which cannot, a priori, be settled unambiguously within this model (even though one can easily state the necessary conditions for total profits to increase as well ${ }^{27}$ ).

\footnotetext{
26 i.e., the elasticity of the wage share with respect to firms' wage targets is equal to one. Qualitatively speaking, this is fully in line with Rowthorn, according to whom "distribution shifts in favour of capital and the share of wages fall" in the wake of a rise in "The target share of capitalists .." (ibid., pp.224-225) 27 Assuming activity and employment to move in proportion (an assumption already implicitly invoked by having ignoed productivity changes), it can be shown that a higher profit share target will indeed, in this model, imply higher total profits if the initial wage share $\omega$ exceeds $1 / 1+\varepsilon$ (or, equivalently, if the employment elasticity $\varepsilon$ of workers' wage share target exceeds the initial ratio between (the share of) profits and (the share of) wages, $(1-\omega) / \omega$ ). It is easy to see why a relatively high value of $\varepsilon$ increases the likelihood that higher profit targets will also lead to higher profits: as seen from (17), a relatively high aspiration elasticity $\varepsilon$ will make the decline of employment and production relatively small; and a relatively small decline of production, in turn, increases the likelihood of higher actual profits
} 


\subsection{Employment and wage-share implications of changed wage and price dynamics}

So far, the only parameters of the wage- and price behaviour we have looked at are the wage share aspirations of workers and firms, respectively. However, a change of the wage and price dynamics (and hence the ensuing potential change of the steady state) does not necessarily originate in changing aspirations, of course, but could also, in principle, reflect changes in the 'dynamic' parameters $\alpha, \beta, \delta$ and $\lambda$. Let us therefore briefly turn our attention to these parameters and examine how steady state employment and the wage share would be affected if, instead, a change of the wage and price behaviour manifested itself through a change in any of these parameters.

\subsubsection{The partial price-to-wage-inflation coefficient $(\alpha)$}

According to (13), an increase in $\alpha$ will make long-run employment decline if imported inflation is positive (implying, in turn, that employment is initially larger than $\left.N^{*} \equiv \underset{N}{\arg }\left[F(N, X)=\omega^{*}\right]\right)$. The impact upon steady-state employment can be written as

$$
\Delta \log N=-\left[\frac{1}{\varepsilon \cdot \beta} \cdot d \log E P^{*}\right] \cdot \Delta a
$$

From (10) and (5), respectively, it is easy to see that this shock will make the $L S E$-locus shift to the left and make the $L S W$-locus rotate counterclockwise (cf. figure $4-1^{28}$ ). Once more, the common sense of all this becomes fairly transparent as soon as this change of the wage dynamics is interpreted in terms of the long-run Phillips curve: unequivocally, a higher $\alpha$ means a counterclockwise rotation of this curve (cf. (6) and figure 4-2), and for a given positive level of imported inflation, long-run employment must therefore shrink.

Actually, (19) could easily have been derived from the long-run Phillips curve (6) and the steady state condition (9): in conjunction they simply imply that

$$
\Delta \log N=-\frac{(\partial(d \log P) / \partial \log \alpha) \cdot \Delta a}{\partial(d \log P) / \partial \log N}=-\left[\frac{\partial(d \log P) / \partial \log \alpha}{\partial(d \log P) / \partial \log N}\right] \cdot \Delta a
$$

In terms of geometry, the numerator of the first RHS-expression in (20) corresponds to the vertical shift of the long-run Phillips curve, whereas the denominator just stands for the slope of this curve (all measured at the initial level of employment); and save for second order changes ${ }^{29}$ the vertical shift over the slope must obviously

28 strictly speaking, figure 4 and figure 5 only cover the cases where $\alpha$ and $\delta$ are both less than one

29 In this context, the usual neglect of second order changes imlied by this type of marginal analysis corresponds to ignoring the fact that the slope of the long-run Phillips curve is changed (marginally) as 
Figure 4: an increase in $\alpha$ and/or $\beta$

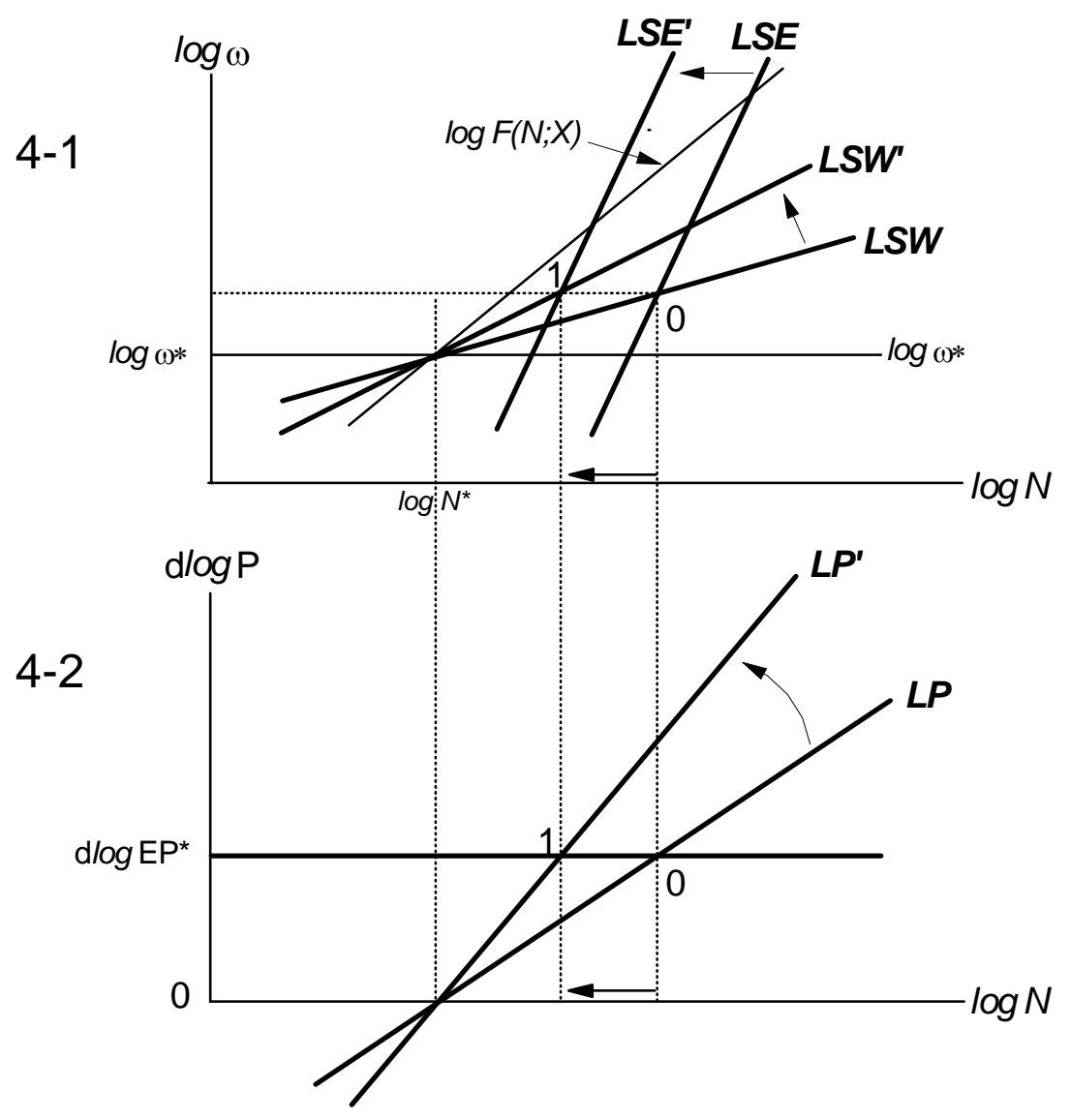

measure the change of steady state employment (cf. figure 4-2). It is easy to verify that the bracketed term in (19) is nothing but a reflection of the bracketed term in (20).

As for the wage share, according to (13) nothing happens. This is fully in line with the previous observation that the wage share is determined recursively by the price dynamics and the steady state condition and hence totally independent of the parameters of the wage dynamics. Save for the case where $\delta=1^{30}$ (implying that $L S W$-locus is horizontal at the level given by the wage share target held by firms), a higher value of $\alpha$ will make this locus rotate counterclockwise. Given $N>N^{*}$, this means that long-run wage share would increase if employment were unchanged. As just seen, however, long-run employment will unambiguously drop, and by itself this drop will tend to depress the wage share. What we have seen is that these two oppositely directed tendencies cancel out precisely, whether or not the $L S W$ rotates.

well

30 Strictly speaking, figure 4 and figure 5 only cover the cases where $\alpha$ and $\delta$ are both less than one 


\subsubsection{The error-correction coefficient of the wage dynamics $(\beta)$}

Qualitatively speaking, the long-run effects on employment of a more swift correction of an error in the form of a discrepancy between workers' wage share aspiration and the actual wage share (as captured by a higher value of $\beta$ ) turn out to be largely identical to the effects of a higher value of $\alpha$ brought out above. From (13) the employment effect emerges as

$$
\text { (21) } \Delta \log N=-\left[\frac{1-\alpha}{\varepsilon \cdot \beta} \cdot d \log E P^{*}\right] \cdot(\Delta \beta / \beta)
$$

For by now well known reasons, a more speedy error correction in the wage formation will leave the long-run wage share totally unaffected (cf. (13)). By and large, the long-run Phillips curve interpretation of a higher value of $\alpha$ presented above applies unchanged here. Apart from the borderline case where $\alpha=$ 1 , a higher value of $\beta$ again means a counterclockwise rotation of the long-run Phillips curve (cf. (6)), and for a given positive level of imported inflation steady state employment must therefore decline. If, however, $\alpha$ should happen to be equal to 1 , the employment impact of a changed value of $\beta$ is seen to vanish completely. This just reflects the fact that, in this case where the $L S W$-locus coincides with workers' wage share target-function $\log F(N, X)$, the long-run Phillips curve (as well as the $L S W$ - locus itself) turns out to be totally immune against a change of $\beta$ (cf. (6) and (5)). In this borderline case, employment as well as distribution will therefore be completely unaffected by this kind of changing of wage behaviour. As seen from (21) and (19), the employment impact of a change of $\beta$ or $\alpha$ (both parameters of the wage dynamics) is not directly ${ }^{31}$ affected by the parameters $\delta$ and $\lambda$ of the price dynamics.

\subsubsection{The partial wage-to-price-inflation coefficient $(\delta)$}

Let me finally turn to the significance of the parameters $\delta$ and $\lambda$ from the price dynamics. According to (13), the long-run effect on employment of a higher value of $\delta$ can be written as

$$
\Delta \log N=-\left[\frac{1}{\varepsilon \cdot \lambda} \cdot d \log E P^{*}\right] \cdot \Delta \delta
$$

Unsurprisingly, the employment impact of $\delta$ is seen to be completely analogous to the employment effect of a higher value of $\alpha$ given by (19). Again, the interpretation is highly facilitated by thinking of the change in terms of our long-run Phillips curve: a higher value of $\delta$ again means, unambiguously, a counterclockwise

31 Insofar as the elasticity $\varepsilon$ is not a pure parameter but depends on employment (which, in turn, also depends on $\delta$ and $\lambda$ ), the employment effect would still be indirectly affected by $\delta$ and $\lambda$ 
Figure 5: an increase in $\delta$ and/or $\lambda$

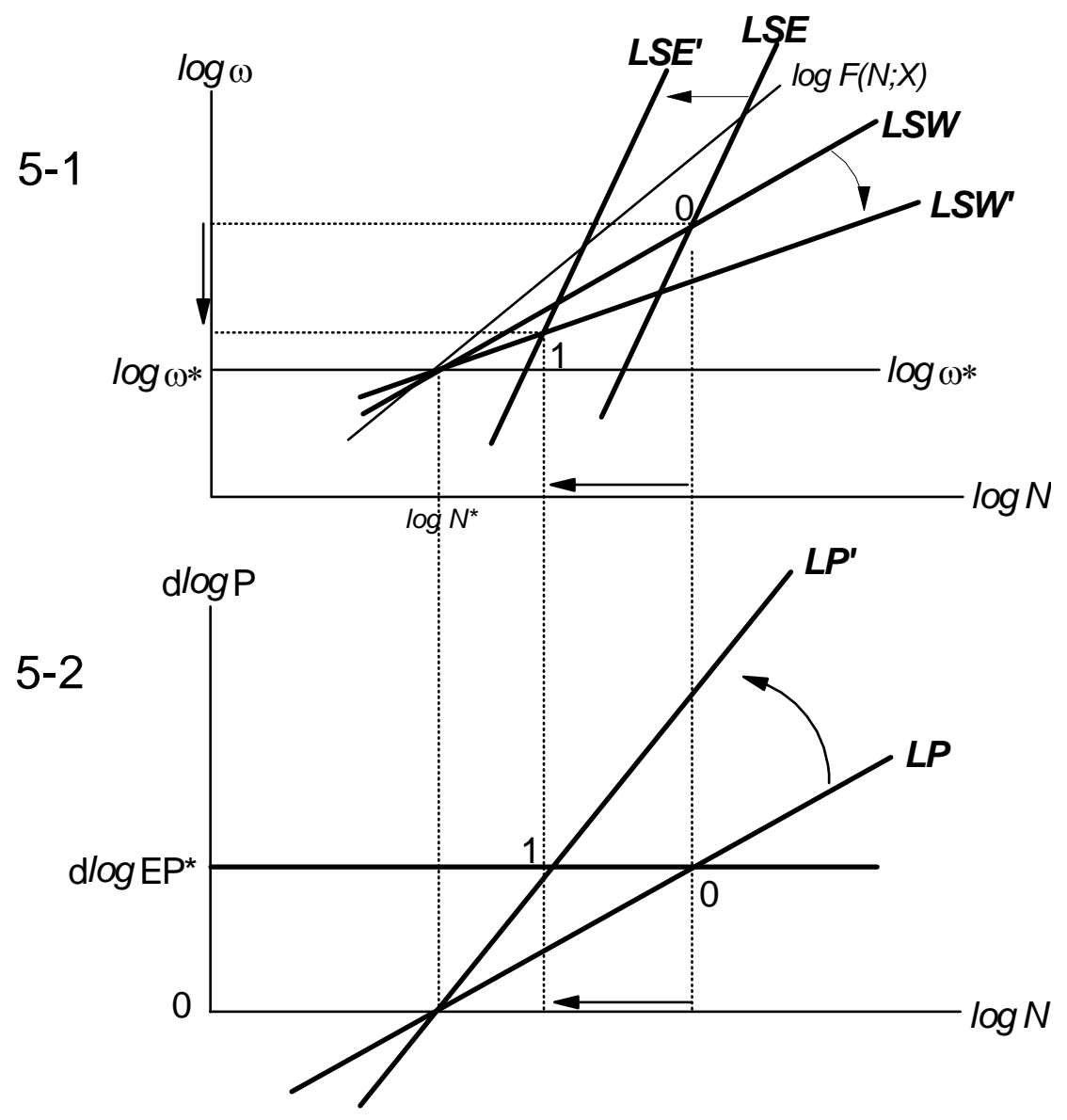

rotation of this curve (cf.(6)) and must therefore imply, for a positive imported inflation, a decline of steady state employment (cf. figure 5-2). As for the wage share things are now quite different: a change of this parameter originating from the price dynamics does not leave the wage share unchanged: from (13) we see that a higher value of $\delta$ will make the wage share decline (provided that imported inflation is positive):

$$
\text { (23) } \Delta \log \omega=-\left[\frac{1}{\lambda} \cdot d \log E P^{*}\right] \cdot \Delta \delta
$$

Once more it is rather easy to explain this decline with reference to the $L S W$-locus and the long-run Phillips curve: save for the case where $\alpha=1$, a higher value of $\delta$ will rotate the $L S W$-locus clockwise (cf. (5)), meaning that the long-run wage share will decline at any given level of employment. As just seen, however, employment will not stay constant but decline. So whether or not the $L S W$-locus rotates, the decline of employment will be sufficient to guarantee a decline of the wage share (cf. figure 5-1). 


\subsubsection{The error-correction coefficient of the price dynamics $(\lambda)$}

From (13) we can finally extract the long-run employment effect of a quicker correction of a gap between firms' wage share aspirations and the actual wage share as

(24) $\Delta \log N=-\left[\frac{1-\delta}{\varepsilon \cdot \lambda} \cdot d \log E P^{*}\right] \cdot(\Delta \lambda / \lambda)$

which, of course, is completely analogous to (21). The impact on the wage share emerges as

(25) $\Delta \log \omega=-\left[\frac{1-\delta}{\lambda} \cdot d \log E P^{*}\right] \cdot(\Delta \lambda / \lambda)$

Again, the long-run Phillips curve interpretation of a higher value of $\delta$ presented above applies almost unchanged here: apart from the borderline case where $\delta=1$, a higher value of $\lambda$ implies, unambiguously, a counterclockwise rotation of the long-run Phillips curve (cf. (6)) and, provided that $\alpha<1$, a clockwise rotation of the $L S W$-locus (cf. (5)) . With a given positive level of imported inflation this means that employment must decline (cf. figure 5-2). If $\alpha<1$ the wage share will therefore decline for two separate reasons. In the borderline case with $\alpha=1$, the $L S W$-locus is unaffected (and equal to workers' wage share aspirations $\log F(N ; X)$ ), whereas the long-run Phillips curve still rotates counterclockwise. Therefore, in this borderline case it is only the drop of employment which accounts for the decline of the wage share.

If, on the other hand, $\delta$ should happen to be equal to 1 , the employment impact of a changed value of $\lambda$ would shrink to zero. The explanation for this, in terms of our geometry, is that neither the long-run Phillips curve nor the $L S W$ locus (which, in this borderline case, fully reflect firms' wage share target $\log \omega *$ ) would be affected at all (cf. (6) and (5)). Consequently, employment as well as distribution would remain completely unaffected by this change of pricing behaviour.

As seen from (24) and (22), the employment impact of a changed $\delta$ or $\lambda$ (both parameters of the price dynamics) is not directly ${ }^{32}$ affected by the parameters $\alpha$ and $\beta$ of the wage dynamics.

From (25) and (23) we infer that the wage share impact of a changed $\delta$ or $\lambda$ is not even indirectly affected by the parameters $\alpha$ and $\beta$ from the wage dynamics.

\section{Concluding remarks}

The basic endeavour of this paper has been to elucidate/bring out the relationship between "modern" error-correction models of wage and price behaviour and, on the

32 see the preceding footnote 
other hand, the older notion of the Phillips curve. It has been shown explicitly that there is no necessary, inherent conflict and that many error-correction models of the wage and price dynamics do in fact imply an "old-fashioned", non-vertical long-run Phillips curve.

It cannot come as a surprise to anybody familiar with the analysis of steady state (un)employment pioneered by, among others, Layard\&Nickell and Rowthorn that long-run unemployment and wage share must be systematically affected by changing real income aspirations of wage earners and/or changing markup-requirements on part of firms. But it may still seem quite strange that the steady state is not, in the analysis above, totally immune to the parameters capturing the error-correction dynamics. Surely, if $\alpha$ and $\delta$ were both equal to one, neither $\beta$ nor $\lambda$ would exert any influence at all upon the steady state. This case would obviously correspond to the notion of a vertical (long-run) Phillips curve (as $\alpha$ and $\delta$ both approach one, the slope of the long-run Phillips curve (6) will obviously become infinite at the employment level $N^{*}$ ). If, however, $\alpha$ and/or $\delta$ are less than one (which, as I have indicated, is a feature of many empirical as well as theoretical model ${ }^{33}$ ) the long-run Phillips curve will have a finite slope, and a change in one or more of the parameters capturing the wage and price dynamics will, at any level of employment, lead to a change of the (finite) level of inflation. And in models like the present one, where inflation in the steady state is constrained and cannot take on any value, steady state employment (and distribution) cannot, therefore, be generally independent of the dynamic specification.

33 The Danish SMEC model is just one example of empirical models displaying this feature, and Cassetti's model, where $\alpha$ and $\delta$ are both equal to zero, can serve as just one recent example of a theoretical model with this property 


\section{Literature}

Blanchard, O.\& Giavazzi, F. (2003) "Macroeconomic Effects of Regulation and Deregulation in Goods and Labor Markets", Quarterly Journal of Economics, pp.879-907

Cassetti, M.(2003) "Bargaining power, effective demand and technical progress: a Kaleckian model of growth", Cambridge Journal of Economics, 27, pp.449-464

Cripps, F.(1977) "The money supply, wages and inflation", Cambridge Journal of Economics, 1, pp.101-112

DS (1996) ADAM - En model af dansk økonomi (Danmarks Statistik, København)

DØRS (1998) "Faktorefterspørgsel og prisdannelse i SMEC", (Konnerup, M., Nielsen, J., Ransby, K. \& Smidt, J.) Arbejdspapir 1998:4, Det økonomiske Råds sekretariat, København

DØRS (1999) "SMEC Modelbeskrivelse og -egenskaber" (Bocian, S., Nielsen, J. \& Smidt, J.) Arbejdspapir 1999:7, Det økonomiske Råds sekretariat, København

DØRS (2007) "SMEC Modelbeskrivelse og -egenskaber" (xxxxx, Arbejdspapir 2007:1, Det økonomiske Råds sekretariat, København

Harck, S.H. (1995) En lille åben økonomi - Nogle makroøkonomiske aspekter, Jurist- og Økonomforbundets Forlag, København (especially chapter 6)

Harck, S.H. (2002)"Reallønsaspirationer, fejlkorrektion og reallønskurver", Working Paper 02-17, Department of Economics, Aarhus Business School

Harck, S.H. (2004)"Reallønsaspirationer, fejlkorrektion og reallønskurver", The Danish Journal of Economics (Nationaløkonomisk Tidsskrift) no. 2, pp.124-136

Harck, S.H. (2005)"AD-AS på dansk", Working Paper 05-11, Department of Economics, Aarhus Business School

Holden, S.\&Nymoen, R. (2002) “Measuring Structural Unemployment: NAWRU Estimates in the Nordic Countries", Scandinavian Journal of Economics 104(1), pp.87-104 
Rowthorn, R.E. (1977) "Conflict, inflation and money", Cambridge Journal of Economics, 1, pp.215-239

Sargan, J.D. (1964) "Wages and Prices in the United Kingdom: A Study of Econometric Methodology" (in Hart, Mills and Whitaker (eds.), Econometric Analysis for National Economic Planning, Butterworth Co., London, pp.25-63)

Solheim, H.O.Aa. (2005) "Evaluating Macroeconomic Modelling with Regard to Usefulness: a Survey, Nordic Journal of Political Economy, vol. 31, pp.3-15

Whitley, J.D. (1994) A course in macroeconomic modelling and forecasting. Harvester Wheatsheaf. 
Department of Economics:

Skriftserie/Working Paper:

2003:

WP 03-1 Søren Harck: Er der nu en strukturelt bestemt langsigts-ledighed i SMEC?: Phillipskurven i SMEC 99 vis-à-vis SMEC 94. ISSN 1397-4831.

WP 03-2 Beatrice Schindler Rangvid: Evaluating Private School Quality in Denmark. ISSN 1397-4831.

WP 03-3 Tor Eriksson: Managerial Pay and Executive Turnover in the Czech and Slovak Republics. ISSN 1397-4831.

WP 03-4 Michael Svarer and Mette Verner: Do Children Stabilize Marriages? ISSN 1397-4831.

WP 03-5 Christian Bjørnskov and Gert Tinggaard Svendsen: Measuring social capital - Is there a single underlying explanation? ISSN 1397-4831.

WP 03-6 Vibeke Jakobsen and Nina Smith: The educational attainment of the children of the Danish 'guest worker' immigrants. ISSN 1397-4831.

WP 03-7 Anders Poulsen: The Survival and Welfare Implications of Altruism When Preferences are Endogenous. ISSN 1397-4831.

WP 03-8 Helena Skyt Nielsen and Mette Verner: Why are Well-educated Women not Full-timers? ISSN 1397-4831.

WP 03-9 Anders Poulsen: On Efficiency, Tie-Breaking Rules and Role Assignment Procedures in Evolutionary Bargaining. ISSN 13974831.

WP 03-10 Anders Poulsen and Gert Tinggaard Svendsen: Rise and Decline of Social Capital

- Excess Co-operation in the One-Shot Prisoner's Dilemma Game. ISSN 1397-4831. 
WP 03-11 Nabanita Datta Gupta and Amaresh Dubey: Poverty and Fertility: An Instrumental Variables Analysis on Indian Micro Data. ISSN 1397-4831.

WP 03-12 Tor Eriksson: The Managerial Power Impact on Compensation Some Further Evidence. ISSN 1397-4831.

WP 03-13 Christian Bjørnskov: Corruption and Social Capital. ISSN 13974831.

WP 03-14 Debashish Bhattacherjee: The Effects of Group Incentives in an Indian Firm

- Evidence from Payroll Data. ISSN 1397-4831.

WP 03-15 Tor Eriksson och Peter Jensen: Tidsbegränsade anställninger danska erfarenheter. ISSN 1397-4831.

WP 03-16 Tom Coupé, Valérie Smeets and Frédéric Warzynski: Incentives, Sorting and Productivity along the Career: Evidence from a Sample of Top Economists. ISSN 1397-4831.

WP 03-17 Jozef Koning, Patrick Van Cayseele and Frédéric Warzynski: The Effects of Privatization and Competitive Pressure on Firms' Price-Cost Margins: Micro Evidence from Emerging Economies. ISSN 1397-4831.

WP 03-18 Urs Steiner Brandt and Gert Tinggaard Svendsen: The coalition of industrialists and environmentalists in the climate change issue. ISSN 1397-4831.

WP 03-19 Jan Bentzen: An empirical analysis of gasoline price convergence for 20 OECD countries. ISSN 1397-4831.

WP 03-20 Jan Bentzen and Valdemar Smith: Regional income convergence in the Scandinavian countries. ISSN 1397-4831.

WP 03-21 Gert Tinggaard Svendsen: Social Capital, Corruption and Economic Growth: Eastern and Western Europe. ISSN 13974831.

WP 03-22 Jan Bentzen and Valdemar Smith: A Comparative Study of Wine Auction Prices: Mouton Rothschild Premier Cru Classé. ISSN 1397-4831. 
WP 03-23 Peter Guldager: Folkepensionisternes incitamenter til at arbejde. ISSN 1397-4831.

WP 03-24 Valérie Smeets and Frédéric Warzynski: Job Creation, Job Destruction and Voting Behavior in Poland. ISSN 1397-4831.

WP 03-25 Tom Coupé, Valérie Smeets and Frédéric Warzynski: Incentives in Economic Departments: Testing Tournaments? ISSN 13974831.

WP 03-26 Erik Strøjer Madsen, Valdemar Smith and Mogens DillingHansen: Industrial clusters, firm location and productivity Some empirical evidence for Danish firms. ISSN 1397-4831.

WP 03-27 Aycan Çelikaksoy, Helena Skyt Nielsen and Mette Verner: Marriage Migration: Just another case of positive assortative matching? ISSN 1397-4831.

2004:

WP 04-1 Elina Pylkkänen and Nina Smith: Career Interruptions due to Parental Leave - A Comparative Study of Denmark and Sweden. ISSN 1397-4831.

WP 04-2 Urs Steiner Brandt and Gert Tinggaard Svendsen: Switch Point and First-Mover Advantage: The Case of the Wind Turbine Industry. ISSN 1397-4831.

WP 04-3 Tor Eriksson and Jaime Ortega: The Adoption of Job Rotation: Testing the Theories. ISSN 1397-4831.

WP 04-4 Valérie Smeets: Are There Fast Tracks in Economic Departments? Evidence from a Sample of Top Economists. ISSN 1397-4831.

WP 04-5 Karsten Bjerring Olsen, Rikke Ibsen and Niels WestergaardNielsen: Does Outsourcing Create Unemployment? The Case of the Danish Textile and Clothing Industry. ISSN 1397-4831.

WP 04-6 Tor Eriksson and Johan Moritz Kuhn: Firm Spin-offs in Denmark 1981-2000 - Patterns of Entry and Exit. ISSN 13974831. 
WP 04-7 Mona Larsen and Nabanita Datta Gupta: The Impact of Health on Individual Retirement Plans: a Panel Analysis comparing Self-reported versus Diagnostic Measures. ISSN 1397-4831.

WP 04-8 Christian Bjørnskov: Inequality, Tolerance, and Growth. ISSN 1397-4831.

WP 04-9 Christian Bjørnskov: Legal Quality, Inequality, and Tolerance. ISSN 1397-4831.

WP 04-10 Karsten Bjerring Olsen: Economic Cooperation and Social Identity: Towards a Model of Economic Cross-Cultural Integration. ISSN 1397-4831.

WP 04-11 Iben Bolvig: Within- and between-firm mobility in the low-wage labour market. ISSN 1397-4831.

WP 04-12 Odile Poulsen and Gert Tinggaard Svendsen: Social Capital and Market Centralisation: A Two-Sector Model. ISSN 1397-4831.

WP 04-13 Aditya Goenka and Odile Poulsen: Factor Intensity Reversal and Ergodic Chaos. ISSN 1397-4831.

WP 04-14 Jan Bentzen and Valdemar Smith: Short-run and long-run relationships in the consumption of alcohol in the Scandinavian countries.

ISBN 87-7882-010-3 (print); ISBN 87-7882-011-1 (online).

WP 04-15 Jan Bentzen, Erik Strøjer Madsen, Valdemar Smith and Mogens Dilling-Hansen: Persistence in Corporate Performance? Empirical Evidence from Panel Unit Root Tests.

ISBN 87-7882-012-X (print); ISBN 87-7882-013-8 (online).

WP 04-16 Anders U. Poulsen and Jonathan H.W. Tan: Can Information Backfire? Experimental Evidence from the Ultimatum Game. ISBN 87-7882-014-6 (print); ISBN 87-7882-015-4 (online).

WP 04-17 Werner Roeger and Frédéric Warzynski: A Joint Estimation of Price-Cost Margins and Sunk Capital: Theory and Evidence from the European Electricity Industry.

ISBN 87-7882-016-2 (print); ISBN 87-7882-017-0 (online). 
WP 04-18 Nabanita Datta Gupta and Tor Eriksson: New workplace practices and the gender wage gap.

ISBN 87-7882-018-9 (print); ISBN 87-7882-019-7 (online).

WP 04-19 Tor Eriksson and Axel Werwatz: The Prevalence of Internal Labour Markets - New Evidence from Panel Data.

ISBN 87-7882-020-0 (print); ISBN 87-7882-021-9 (online).

WP 04-20 Anna Piil Damm and Michael Rosholm: Employment Effects of Dispersal Policies on Refugee Immigrants: Empirical Evidence. ISBN 87-7882-022-7 (print); ISBN 87-7882-023-5 (online).

2005:

WP 05-1 Anna Piil Damm and Michael Rosholm: Employment Effects of Dispersal Policies on Refugee Immigrants: Theory.

ISBN 87-7882-024-3 (print); ISBN 87-7882-025-1 (online).

WP 05-2 Anna Piil Damm: Immigrants’ Location Preferences: Exploiting a Natural Experiment.

ISBN 87-7882-036-7 (print); ISBN 87-7882-037-5 (online).

WP 05-3 Anna Piil Damm: The Danish Dispersal Policy on Refugee Immigrants 1986-1998: A Natural Experiment? ISBN 87-7882-038-3 (print); ISBN 87-7882-039-1 (online).

WP 05-4 Rikke Ibsen and Niels Westergaard-Nielsen: Job Creation and Destruction over the Business Cycles and the Impact on Individual Job Flows in Denmark 1980-2001.

ISBN 87-7882-040-5 (print); ISBN 87-7882-041-3 (online).

WP 05-5 Anna Maria Kossowska, Nina Smith, Valdemar Smith and Mette Verner: Til gavn for bundlinjen - Forbedrer kvinder i topledelse og bestyrelse danske virksomheders bundlinje?

ISBN 87-7882-042-1 (print); ISBN 87-7882-043-X (online).

WP 05-6 Odile Poulsen and Gert Tinggaard Svendsen: The Long and Winding Road: Social Capital and Commuting.

ISBN 87-7882-044-8 (print); ISBN 87-7882-045-6 (online).

WP 05-7 Odile Poulsen and Gert Tinggaard Svendsen: Love Thy Neighbor: Bonding versus Bridging Trust.

ISBN 87-7882-062-6 (print); ISBN 87-7882-063-4 (online). 
WP 05-8 Christian Bjørnskov: Political Ideology and Economic Freedom. ISBN 87-7882-064-2 (print); ISBN 87-7882-065-0 (online).

WP 05-9 Sebastian Buhai and Coen Teulings: Tenure Profiles and Efficient Separation in a Stochastic Productivity Model. ISBN 87-7882-066-9 (print); ISBN 87-7882-067-7 (online).

WP 05-10 Christian Grund and Niels Westergård-Nielsen: Age Structure of the Workforce and Firm Performance.

ISBN 87-7882-068-5 (print); ISBN 87-7882-069-3 (online).

WP 05-11 Søren Harck: AD-AS på dansk.

ISBN 87-7882-070-7 (print); ISBN 87-7882-071-5 (online).

WP 05-12 Søren Harck: Hviler Dansk Økonomi på en Cobb-Douglas teknologi?

ISBN 87-7882-092-8 (print); ISBN 87-7882-093-6 (online).

2006:

WP 06-1 Nicolai Kristensen and Edvard Johansson: New Evidence on Cross-Country Differences in Job Satisfaction Using Anchoring Vignettes.

ISBN 87-7882-094-4 (print); ISBN 87-7882-095-2 (online).

WP 06-2 Christian Bjørnskov: How Does Social Trust Affect Economic Growth?

ISBN 87-7882-096-0 (print); ISBN 87-7882-097-9 (online).

WP 06-3 Jan Bentzen, Erik Strøjer Madsen and Valdemar Smith: The Growth Opportunities for SMEs?

ISBN 87-7882-098-7 (print); ISBN 87-7882-099-5 (online).

WP 06-4 Anna Piil Damm: Ethnic Enclaves and Immigrant Labour Market Outcomes: Quasi-Experimental Evidence. ISBN 87-7882-100-2 (print); ISBN 87-7882-101-0 (online).

WP 06-5 Svend Jespersen, Nicolai Kristensen og Lars Skipper: En kritik af VEU-udvalgets arbejde.

ISBN 87-7882-159-2 (print); ISBN 87-7882-160-6 (online).

WP 06-6 Kræn Blume and Mette Verner: Welfare Dependency among Danish Immigrants.

ISBN 87-7882-161-4 (print); ISBN 87-7882-162-2 (online). 
WP 06-7 Jürgen Bitzer, Wolfram Schrettl and Philipp J.H. Schröder: Intrinsic Motivation versus Signaling in Open Source Software Development. ISBN 87-7882-163-0 (print); ISBN 87-7882-164-9 (online).

WP 06-8 Valérie Smeets, Kathryn Ierulli and Michael Gibbs: Mergers of Equals \& Unequals.

ISBN 87-7882-165-7 (print); ISBN 87-7882-166-5 (online).

WP 06-9 Valérie Smeets: Job Mobility and Wage Dynamics.

ISBN 87-7882-167-3 (print); ISBN 87-7882-168-1 (online).

WP 06-10 Valérie Smeets and Frédéric Warzynski: Testing Models of Hierarchy: Span of Control, Compensation and Career Dynamics.

ISBN 87-7882-187-8 (print); ISBN 87-7882-188-6 (online).

WP 06-11 Sebastian Buhai and Marco van der Leij: A Social Network Analysis of Occupational Segregation.

ISBN 87-7882-189-4 (print); ISBN 87-7882-190-8 (online).

2007:

WP 07-1 Christina Bjerg, Christian Bjørnskov and Anne Holm: Growth, Debt Burdens and Alleviating Effects of Foreign Aid in Least Developed Countries.

ISBN 87-7882-191-6 (print); ISBN 87-7882-192-4 (online).

WP 07-2 Jeremy T. Fox and Valérie Smeets: Do Input Quality and Structural Productivity Estimates Drive Measured Differences in Firm Productivity?

ISBN 87-7882-193-2 (print); ISBN 87-7882-194-0 (online).

WP 07-3 Elisabetta Trevisan: Job Security and New Restrictive Permanent Contracts. Are Spanish Workers More Worried of Losing Their Job?

ISBN 87-7882-195-9 (print); ISBN 87-7882-196-7 (online).

WP 07-4 Tor Eriksson and Jaime Ortega: Performance Pay and the "Time Squeeze”.

ISBN 9788778822079 (print); ISBN 9788778822086 (online). 
WP 07-5 Johan Moritz Kuhn: My Pay is Too Bad (I Quit). Your Pay is Too Good (You're Fired).

ISBN 9788778822093 (print); ISBN 9788778822109 (online).

WP 07-6 Christian Bjørnskov: Social trust and the growth of schooling. ISBN 9788778822116 (print); ISBN 9788778822123 (online).

WP 07-7 Jan Bentzen and Valdemar Smith: Explaining champagne prices in Scandinavia - what is the best predictor?

ISBN 9788778822130 (print); ISBN 9788778822147 (online).

WP 07-8 Sandra Cavaco, Jean-Michel Etienne and Ali Skalli: Identifying causal paths between health and socio-economic status:

Evidence from European older workforce surveys ISBN 9788778822154 (print); ISBN 9788778822161 (online).

WP 07-9 Søren Harck: Long-run properties of some Danish macroeconometric models: an analytical approach.

ISBN 9788778822390 (print); ISBN 9788778822406 (online).

WP 07-10 Takao Kato and Hideo Owan: Market Characteristics, Intra-Firm Coordination, and the Choice of Human Resource Management Systems: Evidence from New Japanese Data.

ISBN 9788778822413 (print); ISBN 9788778822420 (online).

WP 07-11 Astrid Würtz: The Long-Term Effect on Children of Increasing the Length of Parents' Birth-Related Leave.

ISBN 9788778822437 (print); ISBN 9788778822444 (online).

WP 07-12 Tor Eriksson and Marie-Claire Villeval: Performance Pay, Sorting and Social Motivation.

ISBN 9788778822451 (print); ISBN 9788778822468 (online).

WP 07-13 Jane Greve: Obesity and Labor Market Outcomes: New Danish Evidence.

ISBN 9788778822475 (print); ISBN 9788778822482 (online).

2008:

WP 08-1 Sebastian Buhai, Miguel Portela, Coen Teulings and Aico van Vuuren: Returns to Tenure or Seniority ISBN 9788778822826 (print); ISBN 9788778822833 (online). 
WP 08-2 Flora Bellone, Patrick Musso, Lionel Nesta et Frédéric Warzynski: L'effet pro-concurrentiel de l'intégration européenne : une analyse de l'évolution des taux de marge dans les industries manufacturières françaises ISBN 9788778822857 (print); ISBN 9788778822864 (online).

WP 08-03 Erdal Yalcin: The Proximity-Concentration Trade-Off under Goods Price and Exchange Rate Uncertainty ISBN 9788778822871 (print); ISBN 9788778822888 (online)

WP 08-04 Elke J. Jahn and Herbert Brücker: Migration and the Wage Curve: A Structural Approach to Measure the Wage and Employment Effects of Migration ISBN 9788778822895 (print); ISBN 9788778822901 (online)

WP 08-05 Søren Harck: A Phillips curve interpretation of error-correction models of the wage and price dynamics ISBN 9788778822918 (print); ISBN 9788778822925 (online) 